\title{
Combination of Ginger and Sappan Wood Extract Effect on In vivo Antithrombotic Activity Test
}

\author{
Fadlina Chany Saputri', Nida Nabila', Abdul Mun'im² \\ 'Laboratory of Pharmacology, Faculty of Pharmacy, Universitas Indonesia, Depok, 16424, INDONESIA. \\ 'Laboratory of Phytochemistry, Faculty of Pharmacy, Universitas Indonesia, Depok, 16424, INDONESIA.
}

\begin{abstract}
Introduction: Ginger (Zingiber officinale Rosc.) and sappan wood (Caesalpinia sappan L.) have been shown to inhibit platelet aggregation in vitro. Objective: This study aimed to prove the efficacy of the combination of both these plants by examining in vivo antithrombotic activity by the acute pulmonary thromboembolism model in mice experimentally. Materials and Methods: Mice were divided into two experimental groups (bleeding time and survival rate). Acute pulmonary thromboembolism was induced after a combination of ginger and sappan wood extract pretreatment, by an intravenous injection of the mixture of a collagen and epinephrine. The paralyzed and dead mice in each group were observed and the percentage of the protective effect against thromboembolism (survival rate) was calculated. Bleeding time was observed on mice tail that had been cut. Results: The Combination of ginger and sappan wood extract at a dose of $56 \mathrm{mg}$ : $14 \mathrm{mg} / 20 \mathrm{~g} /$ day orally, showed an antithrombotic activity due to preventing the paralysis or death (83.33\%) induced by collagen-epinephrine intravenous injec-
\end{abstract}

tion. The Combination of ginger and sappan wood extract at the same dose also extending the bleeding time of mice significantly $(p \leq 0.05)$ compared with the normal control. Conclusion: Based on these results, a combination of gingersappan extract has a potential effect as an antithrombotic agent.

Key words: Antithrombotic, Ginger, Sappan wood, Bleeding time, Survival rate. Correspondence :

Fadlina Chany Saputri

Laboratory of Pharmacology, Faculty of Pharmacy, Universitas Indonesia,

Depok, 16424, INDONESIA.

Phone no: +62217270031

Email: fadlina.chany@farmasi.ui.ac.id

DOI: 10.5530/jyp.2017.1s.12

\section{INTRODUCTION}

Platelets play an important role in maintaining the integrity of the blood vessels and control bleeding by forming blood clots, but they known to be involved in the thrombosis pathogenesis includes adhering to the vessel injury site, aggregate to form a hemostatic plug or thrombus, and the coagulation cascade acceleration that leads to the thrombosis formation. ${ }^{1}$ Thrombosis means localized clotting of the blood, which can take place within the arterial or the venous circulation and contains a significant medical impact. ${ }^{2}$ Thrombus formed in the circulatory system due to the loss of hemostasis causes vascular blockage, atherothrombotic sicknesses, myocardial or cerebral localized necrosis ultimately prompting death. ${ }^{3}$ The hemostatic process regulation may be a promising approach for the thrombosis prevention or treatment. The development of antithrombotic agents with safer and efficient, including from natural product, is the goal of tremendous pharmaceutical efforts. ${ }^{4}$

Ginger and sappan are examples of herb that has been found in the daily food, drink and widely used as a traditional medicine in Indonesia. Ginger and sappan have been used since kingdom era in Java Island, Indonesia as a health drink and also as herbal medicine to ease cough. ${ }^{5,6}$ Chemically, bioactive components isolated from ginger, 6-gingerol and 6-shogaol in ginger have shown to have a pharmacological activities, such as antitussive, analgesic, hypotensive effects, antioxidant, anticancer, anti-inflammatory, and anti-peptic ulcer. ${ }^{7-9}$ Wood core of sappan contains several aromatic compounds, brazilin, sappan chalcone, Caesalpinia J, caesalpin P, protosappanin A, B protosappanin, homoisoflavonoids $ß$-sitosterol. ${ }^{10}$

This study investigated whether the combination of ginger and sappan extract has antithrombotic properties using in vivo experimental model.

\section{MATERIALS AND METHODS}

\section{Extract and Chemicals}

The test materials used are a readily used water extract of Caesalpinia sappan L. and ethanol extract of Zingiber officinale Rosc. obtained from Java plant. Water extract of Caesalpinia sappan L. that is used contains Brazilin and ethanol extract of Zingiber officinale Rosc. contains 2\% gingerol. Collagen and epinephrine were purchased from Sigma-Aldrich (United State).

\section{Animals}

The animal used in the test is male DDY (Deutschland, Denken, and Yoken) mice purchased from Institut Pertanian Bogor (IPB). The study has been approved by Health Research Ethics Committees of Faculty of Medicine, Universitas Indonesia (Number: 377/UN2.F1/ETIK/2016).

\section{Thromboembolism Mouse Models}

The antithrombotic activity of ginger and sappan extract combination was determined by using pulmonary thrombosis test in the mouse as well as described in DiMinno's method with slight modification. ${ }^{11}$ In brief, combination of ginger and sappan extract in three variants of dose (28 mg : $7 \mathrm{mg} / 20 \mathrm{~g} ; 56 \mathrm{mg}$ : $14 \mathrm{mg} / 20 \mathrm{~g} ; 112 \mathrm{mg}: 28 \mathrm{mg} / 20 \mathrm{~g}$ ) were orally administered as a pretreatment prior to induction. Aspirin $(80 \mathrm{mg} / \mathrm{kg})$ as a positive control were given once per day for 7 days to DDY mice (20$30 \mathrm{~g}$ ). $24 \mathrm{hr}$ after final oral administration of the samples, all groups were induced pulmonary thrombosis by using a solution contain collagen (520 $\mu \mathrm{g} /$ mouse $)$ and epinephrine $(6.5 \mu \mathrm{g} /$ mouse $)$. The mixture solution 
was injected into the tail vein of each mouse. The paralyzed mice were observed and the number of dead mice was counted within $15 \mathrm{~min}$. The survival rate in percentage (\%) was calculated with the following equation: $[1-($ dead or paralyzed mice $) /$ total mice tested $] \times 100 .^{12}$

\section{Bleeding Time Test}

Mice are anesthetized with ketamine (each dose of $100 \mathrm{mg} / \mathrm{kg} \mathrm{BW}$ ). Mice are placed in a horizontal position. About $10-\mathrm{mm}$ segment of the tail is amputated. Then, the tail immediately immersed in a $50 \mathrm{~mL}$ Falcon tubes containing saline $(0.9 \%)$ at a temperature of $37^{\circ} \mathrm{C}$. The tail is positioned vertically, but the tip is about $2 \mathrm{~cm}$ below the body horizontally. Each mouse is monitored for 20 minutes. Although the bleeding stops before 20 minutes, monitoring is still being done to detect the presence of re-bleeding. The bleeding time is calculated by the stopwatch. If bleeding occurs is not constant (missing/signage), the data used is the bleeding accumulated data within 20 minutes. The experiment is discontinued after 20 minutes to prevent the death of test mice during experiments. ${ }^{13}$ The bleeding time percentage by the ginger - sappan extract obtained from the comparison with the normal control group.

\section{Data Analysis}

Bleeding time obtained from each treatment group are then processed statistically. First, data normality was tested by the Shapiro-Wilk test, the results obtained are normally distributed data. Then, the data homogeneity was tested by Levene test, but the results obtained are no data distributed homogeneously, so as to test whether there is a significant difference in the overall data, non-parametric method is used, namely Kruskal-Wallis test whether there is a significant difference in the overall data and the Mann-Whitney test to test whether there is a significant difference between the treatment groups.

\section{RESULTS}

\section{Observation Result of Bleeding Time}

The calculation result of the average time of bleeding time can be seen in Table 1. A normal control group that is given CMC has the average bleeding time of $11.65 \pm 0.877 \mathrm{~min}$. A positive control group that has been given Aspirin has the average bleeding time of $18.75 \pm 0.533 \mathrm{~min}$, which is significantly different $(\mathrm{p} \leq 0.05)$ compared to normal control group. Ginger - sappan wood extract groups dose I, II, and III have the average bleeding time of $12.49 \pm 1.813 ; 15.80 \pm 1.070$; and $13.89 \pm 1.827$ min, consecutively. Based on the analysis data, out of these three extract

Table 1: The observation result of the average time of bleeding time

\begin{tabular}{cc} 
Treatment group & Bleeding Time \\
\cline { 2 - 2 } & Average \pm SEM \\
\hline Normal Control & $11.65 \pm 0.877$ \\
Positive Control & $18.75 \pm 0.533 \#$ \\
Dose I & $12.49 \pm 1.813$ \\
Dose II & $15.80 \pm 1.070 \#$ \\
Dose III & $13.89 \pm 1.827$ \\
\hline
\end{tabular}

Note: Normal controls (0.5\% CMC $0.3 \mathrm{ml} / 20 \mathrm{~g} \mathrm{BW}$ ), positive control (aspirin $0.208 \mathrm{mg} / 20 \mathrm{~g} \mathrm{BW}$ ), dose I (extract of ginger - sappan $28 \mathrm{mg}: 7 \mathrm{mg} / 20 \mathrm{~g} \mathrm{BW}$ ), dose II (extract of ginger - sappan $56 \mathrm{mg}: 14 \mathrm{mg} / 20 \mathrm{~g} \mathrm{BW}$ ), dose III (ginger extract - sappan $112 \mathrm{mg}: 28 \mathrm{mg} / 20 \mathrm{~g} \mathrm{BW}$ ).

\#: Significantly different $(\mathrm{p} \leq 0.05)$ with normal controls groups, dose II group showed a significant difference in bleeding time prolongation compared with normal control group.

\section{Calculation Result of Survival Rate}

Survival rate calculation results obtained from each group after treatment that can be seen in Table 2. Based on the calculation result, normal control group and the positive control group showed $100 \%$ survival rate which means 6 out of 6 mice are alive. The negative control group showed a survival rate of $16.67 \%$ or 1 out of 6 mice is alive. Ginger - sappan wood extract groups dose I, II, and III have a survival rate of 50\% (3 out of 6 mice are alive); $83.33 \%$ (5 out of 6 mice are alive); and $66.67 \%$ (4 out of 6 mice are alive), consecutively.

\section{DISCUSSION}

\section{Bleeding Time Analysis}

Based on the result, a combination of ginger-sappan extract in various dosage levels can increase the bleeding time. However, statistically, the increase of bleeding time that was significantly different ( $\mathrm{p} \leq 0.05)$ compared to the normal control only occurs at a dose of $56 \mathrm{mg}: 14 \mathrm{mg} / 20$ g. Extended bleeding time is due to inhibition of platelet activation and aggregation caused by compounds such as arachidonic acid, thrombin, collagen, ADP (adenosine diphosphate), thromboxane, serotonin, and COX-1 by gingerol and brazilin which are the active components of ginger and sappan. ${ }^{14}$ Inhibition of platelet activation and aggregation can prevent thrombus formation so as to facilitate the circulation of blood. The bleeding time at dose of $112 \mathrm{mg}: 28 \mathrm{mg} / 20 \mathrm{~g}$ and $28 \mathrm{mg}: 7 \mathrm{mg} / 20$ $\mathrm{g}$ were not extended significantly $(\mathrm{p} \geq 0.05)$ will likely be due to dose of $112 \mathrm{mg}: 28 \mathrm{mg} / 20 \mathrm{~g}$ and $28 \mathrm{mg}: 7 \mathrm{mg} / 20 \mathrm{~g}$ were not included in the optimal dose range of ginger and sappan as an antithrombotic agent. A research on the antiplatelet effect of the constituents of ginger indicates that inhibition of platelet aggregation activity undertaken of a constituent will be different at certain concentrations. The study shows that the constituents started to show inhibitory activity at a concentration of 0.1 $\mu \mathrm{g} / \mathrm{ml}$, but the majority of the constituents work optimally in inhibiting platelet aggregation in the concentration range of $100 \mu \mathrm{g} / \mathrm{ml}$. One example is [6]-gingerol that works optimally in inhibiting platelet aggregation induced by collagen and arachidonic acid at concentrations of 20 and 1 $\mu \mathrm{g} / \mathrm{ml}$, whereas [6]-shaogaol work optimally inhibit platelet aggregation induced by collagen and arachidonic acid at a concentration 5 and $1 \mathrm{mg} /$ $\mathrm{ml}$. Although the inhibitory activity also occurs at lower doses and high-

Table 2: Calculation result of survival rate

\begin{tabular}{cc}
\hline Treatment group & Survival Rate (\%) \\
\hline Normal Control & 100 \\
Negative Control & 16.67 \\
Positive Control & 100 \\
Dose I & 50 \\
Dose II & 83.33 \\
Dose III & 66.67 \\
\hline
\end{tabular}

Note: Normal control (CMC $0.3 \mathrm{ml} / 20 \mathrm{~g}$ BW, saline injection), negative control (CMC $0.3 \mathrm{ml} / 20 \mathrm{~g} \mathrm{BW}$, injection of collagen - epinephrine), positive control (aspirin $0.208 \mathrm{mg} / 20 \mathrm{~g} \mathrm{BW}$, injection of collagen - epinephrine), a dose of 1 (extract of ginger - sappan $28 \mathrm{mg}: 7 \mathrm{mg} / 20 \mathrm{~g} \mathrm{BW}$, injection of collagen - epinephrine), a dose of 2 (extract of ginger - sappan $56 \mathrm{mg}: 14 \mathrm{mg} / 20 \mathrm{~g} \mathrm{BW}$, injection of collagen - epinephrine), dose 3 (extract of ginger - sappan $112 \mathrm{mg}$ : $28 \mathrm{mg} / 20 \mathrm{~g}$ BW, injection of collagen - epinephrine). 
er, but the results are not as good as optimal dose. ${ }^{15}$ Some constituents of ginger as gingerol, shogaol and paradol inhibit the activity of COX-1 and collagen, a constituent sappan namely brazilin also shows the inhibitory activity of platelet aggregation induced by collagen and ADP (adenosine diphosphate) in which these activities are also shown by aspirin used as a positive control in this study. ${ }^{14,15}$ This shows the potential constituents of ginger and sappan have the same activity as aspirin that also works optimally at a certain dose. Research conducted by Gan, Teleg, Florento, \& Bitanga in $2002^{16}$ showed that aspirin has inhibitory activity of platelet aggregation induced by collagen in a dose-dependent ranging from 40 $\mathrm{mg} /$ day, but works optimally at a dose of $80-160 \mathrm{mg} /$ day, while the inhibitory activity ADP-induced platelet aggregation (adenosine diphosphate) are shown up to a dose of $1300 \mathrm{mg} /$ day. ${ }^{15}$ Optimal inhibition of COX-1 by aspirin was shown at doses $81 \mathrm{mg} /$ day. ${ }^{17}$

\section{Survival Rate Calculation}

Based on the calculation result of the survival rate, a dose of $56 \mathrm{mg}: 14$ $\mathrm{mg} / 20 \mathrm{~g}$ also showed a higher result compared to the two other doses, although two other doses also have a higher survival rate than the negative control. Dose II group had a survival rate of $83.33 \%$, which there are 5 of 6 mice survival after thrombosis induction. In addition to the possibility of ginger-sappan extract have the same activity as aspirin that works optimally in certain range of dose, the results of the survival rate of a dose of $56 \mathrm{mg}: 14 \mathrm{mg} / 20 \mathrm{~g}$ better than a dose of $112 \mathrm{mg}: 28 \mathrm{mg} / 20$ $\mathrm{g}$ and $28 \mathrm{mg}: 7 \mathrm{mg} / 20 \mathrm{~g}$ may be due to a dose of $56 \mathrm{mg}: 14 \mathrm{mg} / 20 \mathrm{~g}$ was included in certain range of dose that is working optimally in inhibiting platelet aggregation induced by collagen and epinephrine..$^{18}$ Additionally, it also may be due to the active compound of sappan and ginger have a narrow therapeutic window, so that the optimal results actually indicated on the mid dose or dose of $56 \mathrm{mg}$ : $14 \mathrm{mg} / 20 \mathrm{~g}$, not at a dose of $112 \mathrm{mg}$ : 28 $\mathrm{mg} / 20 \mathrm{~g}$ and $28 \mathrm{mg}: 7 \mathrm{mg} / 20 \mathrm{~g}$. At the dose $28 \mathrm{mg}: 7 \mathrm{mg} / 20 \mathrm{~g}$, it is likely the combination of extracts has not reached the minimum concentration drugs to give a therapeutic effect (minimum effective concentration). Then at dose $112 \mathrm{mg}: 28 \mathrm{mg} / 20 \mathrm{~g}$, the combination of extracts may have reached the minimum concentration of the drug to produce toxic effects (toxicity minimum concentration), then the bleeding time and survival rate of the dose of $112 \mathrm{mg}: 28 \mathrm{mg} / 20 \mathrm{~g}$ and $28 \mathrm{mg}: 7 \mathrm{mg} / 20 \mathrm{~g}$ are lower than dose of $56 \mathrm{mg}: 14 \mathrm{mg} / 20 \mathrm{~g}$.

\section{CONCLUSION}

The combination of ginger-sappan wood extract has potential as antithrombotic drugs because it can increase bleeding time and survival rate of test mice at a dose ratio of ginger-sappan wood $56 \mathrm{mg}$ : $14 \mathrm{mg} / 20 \mathrm{~g}$ $\mathrm{BB}$. However, further research is needed to determine the optimum dose and administration duration of ginger-sappanwood extract by increasing the dose starting from the optimal dose from this research gradually and extending the duration of administration.

\section{ACKNOWLEDGEMENT}

This research is supported by Faculty of Pharmacy, Universitas Indonesia and funded by Hibah PITTA Universitas Indonesia.

\section{CONFLICT OF INTEREST}

The authors report no conflicts of interest

\section{ABBREVIATION USED}

DDY: Deutschland, Denken, and Yoken; ADP: Adenosine diphosphate COX-1: Cyclooxygenase-1..

\section{REFERENCES}

1. May AE, Seizer P, Gawaz M. Platelets: Inflammatory firebugs of vascular walls. ArteriosclerThromb Vasc Biol. 2008;28(3):s5-s10.

2. Kabir MSH, Hossain MM, Kabir MI, Rahman MM, Hasanat A, Emran TB, et al. Phytochemical screening, antioxidant, thrombolytic, $\alpha$-amylase inhibition and cytotoxic activities of ethanol extract of Steudnera colocasiifolia K. Koch leaves. J Young Pharm. 2016;8(4):391-7.

3. Dash R, Emran TB, Paul A, Siddique MKU, Khan MA, Rahman MG, et al. Effects of Five Bangladeshi Plant Extracts on In vitro Thrombolysis and Cytotoxicity. Pharmacognosy Res. 2016;8(3):176-80.

4. Mekhfi $H$, Belmekki F, Ziyyat A, Legssyer A, Bnouham M, Aziz M. Antithrombotic activity of argan oil: An in vivo experimental study. Nutr. 2012;28(9):937-41.

5. Madaleno IM. Traditional medicinal knowledge in India and Malaysia. Phcog Comm. 2015;5(2):116-30.

6. Nugroho S. Sehat dan bugar secara alami. Jakarta: Penebar Swadaya; 2006.

7. Bhagat N, Chaturvedi A. Spices as an alternative therapy for cancer treatment. Sys Rev Pharm. 2016;7(1):46-56.

8. Thomson M, Al-Qattan KK, Al-Sawan SM, Alnaqeeb MA, Khan I, Ali M. The use of ginger (Zingiber officinale Rosc.) as a potential anti-inflammatory and antithrombotic agent. Prostaglandins Leukot Essent Fatty Acids. 2002;67(6):475-8.

9. Zaghlool SS, Shehata BA, Abo-Seif AA, Abd El-Latif HA. Protective effects of ginger and marshmallow extracts on indomethacin-induced peptic ulcer in rats. J Nat Sc Biol Med. 2015;6(2):421-8

10. Pawar CR, Landge AD, Surana SJ. Phytochemical and pharmacological aspects of Caesalpinia sappan. J Pharm Res. 2008;1(2):131-8.

11. DiMinno G, Silver MJ. Mouse antithrombotic assay: a simple method for the evaluation of antithrombotic agents in vivo. Potentiation of antithrombotic activity by ethyl alcohol. J Pharmacol Exp Ther. 1983;225(1):57-60.

12. Lee JO, Kim CY, Lee SW, Oak MH. Antiplatelet and antithrombotic activities of Lindera obtusiloba extract in vitro and in vivo. Biomol Ther. 2010;18(2):205-10.

13. LiuY, Jennings NL, Dart AM, Du XJ. Standardizing a simpler, more sensitive and accurate tail bleeding assay in mice. World J Exp Med. 2012;2(2):30-6.

14. Nurtjahja-Tjendraputra E, Ammit AJ, Roufogalis BD, Tran VH, Duke CC. Effective anti-platelet and COX-1 enzyme inhibitors from pungent constituents of ginger. Thromb Res. 2003;111(4-5):259-65.

15. Liao YR, Leu YL, Chan YY, Kuo PC, Wu TS. Anti-platelet aggregation and vasorelaxing effects of the constituents of the rhizomes of Zingiber officinale. Molecules. 2012;17(8):8928-37.

16. Gan R, Teleg RA, Florento L, Bitanga ES. Effect of increasing doses of aspirin on platelet aggregation among stroke patients. Cerebrovasc Dis. 2002;14(34):252-5.

17. Gurbel PA, Bliden KP, DiChiara J, Newcomer J, Weng W, Neerchal NK, et al. Evaluation of dose-related effects of aspirin on platelet function: Results from the aspirin-induced platelet effect (ASPECT) study. Circulation. 2007;115(25):315664.

18. Warner TD, Nylander S, Whatling C. Anti-platelet therapy: cyclo-oxygenase inhibition and the use of aspirin with particular regard to dual anti-platelet therapy. Br J Clin Pharmacol. 2011;72(4):619-33. 